\title{
Usturshona is in the ancient sources (according to Greco- Romanian sources).
}

\author{
Xolboyev Ziyodulla ${ }^{1}$ \\ ${ }^{1}$ Jizzak State Pedogocical Institute, Department of History teaching methods, Uzbekistan \\ Email:ziyodula@umail.uz
}

\begin{abstract}
This article highlites the events passed in the history of Ustrushona, the country that is located in the centre of Middle Asia. There are lots of brief formation of historical informations in it that belong to Diadora, Kvint, Kurtsiy, Roof, Arian, Strabon and Justin.

Keywords: Ustrushona, Greco-Rome historicians, Diador, Kvint, Kurtsiy Roof, Arian, Strabon, Justin, Alexander Macedonian, Khartakanax, Kiropol.

\section{INTRODUCTION}

The earliest written sources on the history of Ustrushana, one of the historical and cultural sites in Central Asia, include works by ancient Greek and Roman authors, Chinese dynasties, and Chinese travelers' diaries.

Ancient written sources give a comprehensive overview of past historical events in Central Asia and adjacent territories, geographical location of the region, ethnic composition of peoples, their customs, localization of the population, existing urban and rural areas. It should be noted that none of the ancient authors created a special work on the history of Central Asia. Because at that time there was no geographical conception of Central Asia [1]. The information provided by the authors of the antiquity is mainly attributed to present-day Central Asia, China, and Eastern Iran, and in some of the works it is mentioned in part on the history and geography of Central Asia. For example, Herodotus gives historically important information about Central Asia. He notes that there are several khokimiyats here, all of which are heavily dependent on the great Iranian state. He referred to the twelfth satrapic of "Bactria's territory to people." Some researchers believe that "the territory of Ustrushana in the ancient twelfth was satrapic and paid tribute to the Achaemenid state" [3]. Most of the information presented is short-lived, and the development of historical events is inconclusive. Generally, it is difficult to create a complete picture of the life of the peoples of Central Asia, including the historical and cultural land of Ustrushona, based on information provided by Greco-Roman authors.
\end{abstract}

\section{MAIN PART}

The Greco-Macedonian armies led by Alexander the Great followed Central Asia in the first century BC. BC In the III-II centuries the authors of the antique period provide information about Central Asia and the territory of ancient Ustrushona in the course of the history of the Macedonian processions. Diador's Historical Library refers to a historical figure called Satibarson who begins to gather in Hartakanah to fight Alexander. It is unique in the beauty of urban nature [4]. The historical figure Satibarzan is not mentioned in the writings of other Greek-Roman historians. About the Hartakanax defense fort. Boynazarov suggests that the historian Diador Khartakanah refers to a place close to Marakand (Samarkand) [5]. However, after the Soghd center and the oasis were occupied by the Greeks, the defenders of the homeland made liberation movements in northern Sughd. In our opinion, this city may be the Kharakana-Kurgantepa town (located in Gallaorol district) in southwestern Ustrushana. The writings of other Greco-Roman authors do not mention the name of a city called Hartakanah. In addition, Alexander will continue his military operations in the historical and cultural cultural centers of Ushtushana after the Sughd oasis. 
Ancient Roman historian Quint Curtius tells in Ruf's book "Alexander the Great of Alexander the Great" that he was seriously injured during the seizure of Kiropol on the northern border of Ustrushana. In September-October 329, Ustrushona is reported to have been attacked by seven townspeople. Curtius Rouf states in his work that Alexander's army surrendered Gaza and four cities in two days, and that the locals showed great courage in capturing the city of Cyropol and the tribes of the Mimekians.

The Greek historian Arrian also states that Alexander was severely wounded during the battle, saying that "some of the mountain peaks were destroyed and many of them died from the rocks, and 8,000 to 8,000 were saved". It is not known exactly what mountainous area of Ustrushana was mentioned in these historical details. Arrian, in the novel "The Alxander's Walk" in the "Ostrushona" oasis, said that "within two days Alexander's troops would capture five of the seven cities. The sixth city was the largest, the name of which was called Cyrus. This city is called Kiropol because it was built by Cyrus "[9]. The authors of the antiquity acknowledge that the Greek-Macedonian armies suffered severe resistance and military strikes from the peoples of the Yaksart Basin.

Seven towns in the aforementioned Syrdarya Basin revolt against Alexander the Great. Cyropol was the largest of the rebel-held cities and the strongest in defense. Arrian said that "this city, founded by Cyrus, was surrounded by much higher walls than any other, and with a large number of militia, it was difficult for the Macedonians to capture it at the first attack." gives. Strabon describes "the most remote town founded by Cyrus on the Yaksart River", and Justin tells Chek Alexandria that "the inhabitants of the three towns that had been revolted by Cyrus" moved [11].

According to the authors of the antique period, Justin writes that Alexander will build 7 cities in Bactria and Sogdiana. One of them is Alexandria Eskhata, built on the Yaksart (Syrdarya) river. This city will be completed very quickly - seventeen days. The walls of the city were six thousand steps [12]. According to scientists, this city was built in the place of present-day Khujand. However, Professor M.Lyutov notes that the city of Eskhata in Alexandria was built not far from what is now Khujand, but near Bekabad in the Syrdarya[13].

\section{CONCLUSION}

To summarize, we can say that the history of the Ustrushana historical-Madanians dates back to the Greco-Roman sources, but the historical data presents many misunderstandings, controversies, and suspicions in the text. Many sources have different interpretations of the same event and the individuals involved. Nevertheless, the writings of Greek-Roman historians serve as the primary source for the study of the history of Ustrushana.

\section{REFERENCES}

1. Холбоев 3., Холбоева М. Ўрта Осиёнинг тарихий-маданий ўлкалари. Т., "VneshInvestProm", 2016, 45-б. (Kholboyev Z., Kholboyeva M. The historic-cultural lands of Central Asia. Tashkent, "VneshInvestProm", 2016, p. 45.).

2. Герадот. История. Перевод и примечания Г.А. Стратановского. (В 9кн). -М.: 2002. с.209. (Heradotus. Historiy. Translation and notes. G.A. Stratanovsky. (in 9 books). Moscow. 2002. p. 209.).

3. Билалов А.И. Из истории ирригации Уструшаны. -Душанбе: Дониш. 1980. c.81. (Bilalov A.I. From the history of irrigation of Ustrushana. - Dushanbe, “Donish”, 1980, p. 81.).

4. Диадор. Историческая библиотека. Строгецкий В.М. Введение к "Исторической билиотеке" Диадора Сицилийского и его историко-философское содержание. СанктПетербург, при ИМП АН., 1774, стр. 521. (Diador. Historical library. Strogesky V.M. Inforduction to "Historical library" of the Diadora of Sicily and its historical and philosopfical content. St. Petersburg. at IMP. AN., 1774, p. 21.).

5. Бойназаров Ф. Ўрта Осиёнинг антик даври. Тошкент, “Ўқитувчи”, 1991. 109-бет. (Boynazarov F. the Ancient age of Central Asia. Tashkent, "Educator", 1991, p. 109.). 
6. Квинт Курций Руф. История Александра Македонского. Сохранившиеся книги. Издательство Московского университета. 1963. С. 279. (Quintus Curtius Rufus. The history of Alexander. Survirng books. Moscow University Press. 1963. p. 279.).

7. Квинт Курций Руф. История Александра Македонского. Сохранившиеся книги. Издательство Московского Университета, 1963. С. 273-275. (Quintus Curtius Rufus. The history of Alexander. Survirng books. Moscow University Press. 1963. p. 273-275.).

8. Арриан. Поход Александра. Изд-во. АН СССР. М-Л., 1962. с.155. (Arrian. The Anabasis of Alexander. ANSSSR Press. M-L., 1962. p. 155.).

9. Арриан. Поход Александра. Изд-во. АН СССР. М-Л., 1962. с.134. (Arrian. The Anabasis of Alexander. ANSSSR Press. M-L., 1962. p. 134.).

10. Арриан Флавий. Анабасис Александра или история паходов Александра Великого. Пре. с древнегреч. М.Е. Сергеенко. -М.-Л., Изд. АН СССР. 1962. с. 155. (Arrian Flavius. The Anabasis of Alexander or the history of the wars and conquests of Alexander the Great. M.E. Sergeenko. M-L. ANSSSR Press. 1962. p. 155.).

11. Негматов Н.Н. Уструшана в древности и раннем средневековье. -Сталинабад. 1957. с. 17. (Negmatov N.N. Usturshana in antiquity and early middle ages. Stalinabad. 1957. p. 17.).

12. Гафуров Б. Таджики. Изд-во "Наука". М., 1972. с.96. (Gafurov B. Tajiks. Press "The science". М. 1972. p. 96.).

13. Лютов М.М. Александр Великий в Туркестане. Ташкент, типо-литография С.И. Лахтина, 1890, c.17. (Lutov M.M. Alexander the great in Turkistan. Tashkent, typolithography S. I. Laxtin. 1890. p. 17.). 